\title{
Rewards Management in Organizations: A Retrospective on what Organizations Have Set out and achieved in order to Identify Future Actions
}

\author{
Radu MARIN \\ National University of Political Studies and Public Administration, Bucharest, Romania, \\ radumarin62@gmail.com
}

Received date:25 November 2020; Accepted date: 9 February 2021; Published date: 26 July 2021

Academic Editor: Agatha Popescu

Copyright (C 2021 Radu MARIN. Distributed under Creative Commons Attribution 4.0

International CC-BY 4.0

\begin{abstract}
The current paper's objective is to highlight the idea that the companies should aim to implement an efficient total reward management, in order to attract, retain, motivate and improve the performance of its employees. Different types of rewards which can be offered to employees and the evolution over time of employees' preferences for every type will be analyzed. This evolution has led to the transition from the compensation model to total rewards management model. By analyzing the studies published so far, the paper will present ways in which total rewards management can be effectively used within companies. The paper will also demonstrate that total rewards management has a determining role for increasing the performance of companies. The paper aims to present the influence of the entire package of rewards that can be offered by companies to their employees, given the fact that many of the studies published so far have focused only on the analysis of one or several rewards. This paper also aims to identify the full package that will be most appreciated by employees based on cultural, gender and age differentials.
\end{abstract}

Keywords: compensation management, total rewards management, employee attraction, motivation and retention, company performance

JEL Classification: J33, M52, M54.

Cite this Article as: Radu MARIN (2021)," Rewards Management in Organizations: A Retrospective on what Organizations Have Set out and achieved in order to Identify Future Actions", The Journal of Organizational Management Studies, Vol. 2021 (2021), Article ID 642473, DOI: 10.5171/2021.642473 


\section{Introduction}

The present paper will analyze which were the factors that influenced the personnel policies chosen by the companies and determined the transition from compensation management to total rewards management. The role of compensation management is to design and implement within companies the full compensation package. In the literature, this is also known as salary administration, payroll management, reward management, although, as we will see in this paper, these concepst are either restrictive or too permissive regarding the rewards that are administrated within compensation management. In our opinion, we consider the concepts of salary administration and payroll management as being limited. Although they still have an important role in employees' preferences, they represent only a fragment of the rewards that can be offered to employees. Also, these concepts have a lesser impact on employees in the modern economy, especially on highly qualified employees, who, in general, have attractive salary packages by default. In our opinion, the use of the term compensation management is due to the fact that employees perceive the rewards received from the organization as compensation for their efforts, as compensation for the time spent working, in the expense of personal life. From a semantic point of view, perhaps the term of compensations better defines the fact that the rewards they contain are practically something offered in exchange (a compensation) for the employees' activity. On the other hand, in the modern view, compensations contain only the basic salary, bonuses, profit sharing or the option to buy shares, meals at the company's canteen, different types of free subscriptions offered by the employer (practically all those rewards that have a financial expression). Total rewards add additional categories of rewards to the ones included in the compensation, which can take a variety of forms: health insurance, retirement plans, sickness insurance, incapacity for work, unemployment, life insurance, paid leave and any other benefits that employers can provide (flexible schedule, personal development and career development programs, a good worklife balance, job recognition programs). In addition, the difference between compensation and total rewards can also be seen in terms of time: while compensations reflect present or past rewards given for employees' activity, total rewards have an openness to the future. However, there are also organizations that have a broader view of the concept of compensation, including a number of benefits that generally exceed this notion, such as health and life insurance, retirement plans.

\section{Research outline}

We have aimed to analyse the studies published in the last two decades in order to identify the way in which employees' preferences have changed towards certain rewards and how companies understood to respond to those changes. Another goal of the study is to highlight how organizations' performance can be influenced in a favourable way by adopting the correct rewards package.

Gross and Friedman (2004) considered that the structure of rewards granted by the employer has changed due to the fact that employees' preferences for rewards have changed. Thus, if in the past employees were asking questions about how much they currently earn or how consistent their retirement plan will be, more and more employees are starting to ask questions about how much the whole rewards package will be over their entire activity in an organization. In the modern economy, based on knowledge and globalization, attracting and retaining a highly skilled workforce within organizations is essential in order to achieve the desired level of competitiveness and performance. In this regard, McCormick (2015) highlighted the opinion of successful companies that a comprehensive plan in terms of overall reward strategy can lead to differentiation 
from competition, attracting highly qualified employees and increasing the productivity, obtaining a better yield. This is why Bwowe and Marongwe (2018) consider that many organizations pay much more attention to the restructuring of the reward system, given its positive effect on employee motivation and retention. Rumpel and Medcof (2006) also consider that the implementation of a total reward system can bring the following functional benefits to the organization: attracting, motivating and retaining employees. Keeping the same approach, Adeoye and Fields (2014) considered that implementing a rewards management system allows the companies to gain a competitive advantage, due to the fact that they will attract qualified personel that can be transformed in a stable workforce. Moreover, Milne (2001) considers that, besides encouraging employee engagement, implementing a reward system will also contribute in an essential mode to the knowledge sharing behaviour among employees.

Another important aspect, in terms of the benefits gained due to compensation management, is analyzed by Greene (2014), which considers that the existence of a state of commitment, satisfaction and motivation among employees causes them to be more productive and more involved in relationship with the organization. The author concludes that, due to this fact, organizations have begun to consider employees involved in work as valuable resources. In the same direction, Maung and Walsh (2016) present the employees efforts as determinants for the success and survival of organizations and consider the reward system as an essential factor for obtaining employee motivation. We find the same idea presented by Bustamam and Abdullah (2014), which considers the implementation of a reward system within organizations as an essential management tool, which, by increasing employees' motivation and satisfaction, contributes to increasing the performance of the organization. In this regard, Adeoye, Atiku and Fields (2016) note that the main reason for awarding rewards is to shape employees' behavior in the direction that the organization needs them to go. Fernandes (1998) pointed out that, in order to increase productivity and ensure the attraction and retention of key employees, many employers have been forced to revise their reward policies. However, the author points out that certain rewards such as freedom, flexibility and delegation of decisions to employees can also lead to adverse effects, such as abusive entry into the employees' private space and the transfer of risks to the employee. Heneman (2001) pointed out that, although the specyalised literature considers compensation policies to have a positive impact on the organization's efficiency, there is still very little information on how they can be linked to the organizations' business strategy. We find this idea also expressed by Dessler (2016), who stressed that a compensation package must be created in ordert to gain a competitive advantage, by modeling the desired behavior among employees, respectively to create a link between each type of rewards and a specific business objective. The author concludes that this is why many organizations use a total rewards strategy to support achieving their goals, noting that this strategy adds more challenging work, career development and recognition to the traditional rewards, such as payments, incentives, and benefits. Based on the theory of equity, the author considers that the award of compensation must be fair both externally, in terms of awarding rewards within the organization in relation to rewards for similar activities in other organizations, and internally, respectively equity in terms of rewards for various activities within the organization. Awarded rewards should also be fairily distributed among employees performing comparable activities and the processes and procedures established for awarding compensation must be perceived by employees as being fair (Dessler, 2016). Day, Johnson and Barron (2014) also present the fact that the resources allocation is generally influenced by three criteria, two of which are equality and equity. In the same direction, Bwowe and Marongwe (2018) find that, in order to promote fairness and correctness to 
different categories of employees, organizations must link performance rewards, otherwise it can become very difficult for organizations to offer the deserved recognition, which would lead to incorrectness.

Aksakal and Dağdeviren (2014) view rewards as what is offered in exchange for desired behavior, as a factor in motivating employees to have flexible and better performance and reward management, whose main goal must be to properly reward employees, must ensure the creation of the reward structure that operates within the organization. The authors believe that rewards management should focus on both financial and nonfinancial rewards. We can observe that, in the article, the authors believe that reward management must be based on two motivation theories: the theory of equity, because it emphasizes that its main objective is to properly reward employees, and Skinner's theory because it considers the rewards to be a positive consolidation.

\section{Findings}

\section{Reward Packages Evolution}

Bussin and Van Rooy (2014) highlight a major problem that may arise if an unitary structure is to be implemented in terms of the reward policies adopted, namely the fact that, depending on the generation the employees are part of, certain types of rewards can be different. In today's organizations, with employees from multiple generations, choosing this type of unitary reward policies could lead to the impossibility of obtaining the desired result, namely the attraction, motivation and retention of employees. This, the authors conclude, could have a negative effect especially on labor markets with few highly and medium skilled workers, especially in the context of increased labor mobility (Bussin and Van Rooy, 2014).

Another aspect regarding the rewarding strategy is highlighted by the Worldatwork study (2015) which shows that HR specialists agree that the company's business strategy must be the foundation for implementing human resources policies and developing a strategy for rewarding employees. Khan, Aslam and Lodh (2011) considered compensation management to be very important so that organizations do not end up having problems and an important means that companies have at their disposal in trying to attract and retain valuable employees. Compensation policy is considered being part of human resources policies. The authors defined compensation as being represented by all forms of payment obtained by employees as a result of their work, but noted that the compensation includes both financial and non-financial rewards. The definition was taken from Dessler (2016) who considered salaries, incentives, commissions and bonuses as direct financial payments, and financial benefits such as insurance and paid leave as indirect financial payments.

Medcof and Rumpel (2007), based on the findings of previous studies, stated that total rewards include everything an employee appreciates in the relation with it's employer, including payments, benefits, a challenging work, learning and career development and work / life effectiveness, but not limited to them. Therefore, they believed that establishing a package of total rewards should be based on an inventory of rewards that the organization has the opportunity to offer to its employees, but also on a study of the importance that each of these rewards has for employees (Medcof and Rumpel, 2007).

Martocchio (2017) considers compensation to be composed of intrinsic and extrinsic rewards received by employees in exchange for their work and membership in the organization.

Fernandes (1998) emphasized that employers should review their reward strategy so that, on the one hand, they can identify the most effective rewards and, on the other hand, strengthen the business objectives, showing that reward strategies must seek to motivate those employees who 
pursue both career-related aspirations, and the achievement of the business objectives of the organization. In the same approach, Kaplan (2007) shows that the strategy regarding total rewards is "a holistic approach that aligns with business strategy and people's strategy", considering that it refers to everything that employees value in the relation with their employers. Gross and Friedman (2004) noted a paradigm shift in total rewards programs: while organizations initially viewed this type of program as a useful tool that can be used for attracting and retaining employees, over the time they began to aknowledge the role that employees have in achieving business objectives.

The study carried out by Alhmoud and Rjoub (2020), based on the finding that the current labor market is dominated by Generation $X$ and Generation Y, sought to determine the extent to which different types of rewards impact employee retention. The authors divided the rewards into three categories: extrinsic, intrinsic and social. The conclusions of the study, although limiting as highlighted by the authors, given that the research was conducted in a single field of activity and in a single country, revealed that, in terms of retention among representatives of both generations, the role of the extrinsic rewards is decisive, neither of the two generations being influenced by the social rewards. The study concluded that, in terms of retention, intrinsic rewards are more appreciated by representatives of generation $\mathrm{Y}$ and are of no interest to those in generation X (Alhmoud and Rjoub, 2020).

Robbins, DeCenzo, Coulter and Anderson (2013) also believed that employees can be motivated to behave appropriately by applying a fair reward program, and based on previous studies concluded that not all employees think that money are the most important reward. Based on a 2000 study conducted in Canada, the authors stated that, in terms of employee satisfaction, paycheck and benefits matter less than a reliable top management and a good work-life balance (Robbins, DeCenzo, Coulter and Anderson
(2013). Based on these considerations, the authors proposed adding to the reward package employee performance recognition programs and performance-based payment programs, stock options and improved worklife balance (flexible work schedule, work sharing, telework). The paper presented by Pregnolato (2010) indicates that, in terms of employee retention, in the total reward package the components have the following importance: benefits (35.2\%), performance and recognition (20\%), remuneration (17\%), the possibility to advance in career $(10.3 \%)$, the learning opportunity $(9.1 \%)$ and the work-life balance $(8.4 \%)$. The paper found relatively small gender differences in preference for one or other of these components. With regard to age categories, it was found that, while for Baby Boomers and generation $\mathrm{X}$ the preferences follow the general rule, generation $Y$ follows the general rule for four components, while in terms of work-life balance it is considered fourth in the order of preferences, while career advancement ranks last in importance.

Bussin and Toerien (2015) also conducted a study in South Africa, as in the previous study, but only on the workforce operating in the IT sector, considering the total rewards model developed by WorldatWork. The study found that there was an additional problem in establishing and implementing a total rewards package, due to the fact that employees' preferred rewards differed significantly in the three study scenarios, namely to join an organization, to be motivated within an organization and to stay within an organization. However, analyzing the total rewards preferred by employees, the study found that the components of compensation (salary, incentives and bonuses) retain their predominant importance, benefits being also considered very important (health insurance, retirement plans) and also rewards related to work-life balance, life and flexible work schedule. Management quality has been identified as the most important reward in employee preferences. 
Rumpel and Medcof (2006) show the relationship between total rewards and compensations. The authors state that, in order to increase productivity, to reduce the employee desire to leave the company and to increase employee engagement, organisations can implement flexible working hours, training programmes, career development opportunities and a strong performance management and they can integrate them with monetary compensations. In this way, it can be achieved something that the authors define as "employee value proposition", meaning all that the employees receive in exchange for their work within organization (Rumpel and Medcof, 2006). In this respect, Jiang, Xiao, Q and Xiao (2009) state that rewards are a compensation received by the employee in exchange for it's work and it can be monetary or it can be converted into a monetary form and also it can have non-monetary forms, such as: stable work place, good relationship with colleagues, decision making involvement, challenging tasks, development opportunities. Keeping the same approach, the authors define total rewards as being formed of monetary payments, benefits, flexible working hours, educational assistance and all the opportunities offered in order to achieve both professional and personal performance. The authors highlight that, although the term total rewards is assimilated to the one of total compensations, total rewards represents all the elements that employees appreciate in the relation with their employer and it is the most modern term related to rewards (Jiang, Xiao, Qi and Xiao, 2009). The authors started from the term total rewards introduced by Fernandes (1998), who defined it as "the sum of the values of each element in the employee's reward package".

Although organizations have been trying for a very long time to align total reward management with the organizations' business strategy, Deloitte (2018a), having as starting point the Bersin Deloitte Consulting LLP "High-impact Total rewards research" 2018 study, points out that only a small percentage of respondents perceive the rewards offered by organizations as very effective in driving business outcomes. The study revealed that respondents consider the rewards offered by their organizations to be "very effective" in driving business outcomes in the following proportion: alignment with business goals $(12 \%)$, talent retention (8\%), talent attraction (6\%), talent growth and development (5\%) and talent motivation (3\%). A possible response to these results was provided by Deloitte (2018b, p. 33-35) which found out that total reward packages do not align with employees' preferences in three aspects: 1 . employees have a more favourable reaction to agile compensation granted more often than those granted on an annual basis; 2 . organisations fail to create a wider range of rewards, which would lead to a more diverse workforce, because they do not try to better understand employees' preferences; 3 . employees do not perceive many of the current reward programs as being fair.

\section{Total Rewards Model Evolution}

Armstrong and Brown (2006), consider that a functional reward model for the 21st century will have to focus on the growth of employees' involvement as they should be motivated and productive. The authors believe that a reward system should be based on four core values: fairness (people should be rewarded based on their contribution to the organization, and employees should feel that the rewards are fair), equity (equal rewards for the same type of work), consistency (rewards are not set arbitrarily and do not differ in time or between different people) and transparency (employees understand how the rewards system works and how it will affect them) (Armstrong and Brown, 2006).

Brown (2018) developed a total rewards model, defining the terms of total rewards, total remuneration, total compensation and total cash. Total cash paid to employees has as rewards basic payments (basic salary, hourly salary) and short-term variables (annual incentives, individual bonuses, team bonuses). Adding to the total money the long- 
term rewards / incentives (stock/equity, profit shares), the total compensations are obtained. If passive benefits (retirement plan, health and well-being plans, paid leave) and active benefits (business car, professional memberships, discounts) are added to these, the total remuneration is obtained. All these classes of reward elements are considered by the author to be extrinsic and a monetary value can be associated with them. If an element containing extrinsic rewards is added to total remuneration, meaning engagement factors (quality of work, growth opportunity, enabling environment, work-life balance, inspiration/value), a total reward system will be obtained.

Milkovich, Newman and Gerhart (2014) defined compensation as being represented by "all forms of financial rewards, tangible services and benefits that employees receive as part of the employment relationship". Taking these considerents as starting point, they presented a total returns structure that employees receive in exchange for their work within the organization, structure containing two rewards categories: compensation (monetary compensation and benefits) and relational rewards. Monetary compensation is formed of: basic salary, periodic monetary compensations (with adjustment role, which can be both performance-based salary increases, with the role of providing similar payments for similar work, and increases with the role of rewarding developments in terms of experience or qualifications or to offset increases in living costs), short-term incentives (performance-based payments, granted on a regular basis and based on previously communicated criteria) and longterm incentives, respectively those incentives granted to reward efforts that employees made over a longer period of time (the option to receive or buy shares at a set price). Benefits consist of: 1. those measures taken to protect the income of employees (income insurance during periods when, for various reasons, the employees are unfit for work or lose their job, health insurance, life insurance, savings programs and retirement programs), 2. work / life balance (which allows employees to integrate employee responsibilities with those related to personal life) and 3. allowances (for accommodation, transport). Relational rewards are related to recognition and status, employment security, challenging work and learning opportunities (Milkovich, Newman and Gerhart, 2014).

Tropman (2001) considers total compensation as an equation with ten unknown exponents: 1 . base pay or salary (which, as the author notes, represents for the organization the highest cost in total compensation); 2 . augmented pay (representing those payments granted on a one-time basis consisting of overtime payments, incentive payments, profit sharing and stock options); 3 . benefits (unemployment insurance, health insurance, social insurance and retirement fund set up by the employer); 4. providing work equipment; 5. offering discounts for the purchase of the company's products; 6 . advancement opportunity; 7. development opportunity; 8. psychic income (emotional rewards or disappointments related in particular to work itself and to relationships with colleagues and superiors); 9. quality of life (representing the relationship between professional activity and personal life, the way in which they intertwine); 10.the factor named by the author factor $\mathrm{X}$. This factor refers to the special needs and desires of specific categories of employees, needs and desires that redefine their expectations in relation to employers. The author considers that it is the role of the compensation manager to identify the specific needs defined by the $\mathrm{X}$ factor. $\mathrm{He} /$ she must be proactive and have the ability not only to solve employees' requests, but also to generate requests from employees, by consulting them on their preferences.

Armstrong and Taylor (2014) considered that the reward strategy and the business strategy must be integrated and they defined the need to establish a reward strategy. This was designed to help both establish the reward system that the organization wanted to develop in the future and the steps to be followed in order to implement this system. 
The authors pointed out that this reward system should lead to benefits for both the organization and its employees. The constructed model considered that the total reward package should encompass both the financial rewards, considered by the authors as representing the total remuneration and representing the transactional rewards, and the non-financial or intrinsic rewards, considered by the authors to be relational rewards. The first class of rewards included, in the authors' opinion, the basic salary, contingent pay and employee benefits, and the second the attractiveness of work itself, work experience, non-financial recognition, achievement and growth (Armstrong and Taylor, 2014).

It is very interesting how WorldatWork has developed models on total rewards. The original model was developed in 2000 and was based on the interaction of the total reward strategy with the organization's strategy and employee results. The model considered that the reward strategy is based on the following five components: compensation, well-being, benefits, development and recognition. The stated purpose of the model was to lead to a productive, inspired and commited workforce. WorldatWork believed that, in order to implement a correct total rewards model, organizations must also take into account external influences. WorldatWork has always sought to improve the total rewards model. The model published in 2006 changes the five components of the reward strategy. Compensation and benefits were maintained, adding work-life balance, performance / recognition and development / career opportunities. The implementation of this model was to contribute to the attraction, motivation and retention of employees. The last change was made to the model in 2015. The model was based on a six-component rewards strategy. The two components that remained unchanged were compensation and benefits. The other four components that complemented the reward strategy were: work-life efficiency, recognition, performance management and talent development. This reward strategy was considered to contribute to employee attraction, motivation, retention and engagement. What should be noted is that at each change to the model, WorldatWork presented a total rewards inventory that broadly defined the rewards that can be awarded within each component of the total rewards strategy.

\section{Discussions}

As a first objective, this paper aims to analyse the evolution of the categories of rewards offered by organisations. The research was based on empirical studies, surveys, reports and books that have addressed this topic in recent decades. The two concepts used by organizations to manage employee rewards were analyzed: compensation management and total reward management. Based on the research carried out, we can say that there is still a confusion in the literature between the term of compensation and that of total rewards, often considering the two reward schemes to be identical. We consider that, while the compensation package includes only salaries, bonuses and, in some approaches, a number of benefits, representing practically costs of the organization, made to reward human resources, the total reward system should be seen as a summation of the investment that the organization makes in its own employees (compensation, ensuring personal and professional development) with those factors that make employees appreciate the fact that they work for a particular organization, such as career advancement, flexible work schedules, a good work-life balance.

The second objective of the paper was to identify any differences in employees' preferences in terms of a particular type of reward, based on age and gender criteria. We considered this analysis to be important, taking into account that in the current labour market we find a great generational variety, and women are taking on an increasingly important role. The results of the research revealed that, while the rewards awarded under the compensation package still play a 
very large role, organisations will have to pay increasing attention to those rewards related to good effectiveness of both work and personal life, recognition of employees' efforts and performance, effective performance management and talent development.

The third objective of the article was to analyze a number of models on the total rewards developed in recent decades. The study of these models was done in order to have a better understanding on how they helped define and explain the contribution that current reward packages make to achieving employee satifaction and business goals. We believe that the total rewards model developed and continuously improved by the WorldatWork Association can be currently used successfully to implement total reward management. The total reward management can be adapted in the future, based on the evolution that will take place in terms of rewards, bearing in mind both the dynamic relationship between employees and organizations and the external influences that are faced by organisations. It should be noted that the article did not intend to present all the models that were developed during this period of time, considering that it is sufficient to present only those models that have definitely contributed to the development of the management of total rewards.

\section{Conclusion}

The conclusions drawn from the analysis of the works published so far show that the need to implement a system of total rewards has arisen with the aim of supplementing and diversifying the compensation system. From an organization perspective, this was necessary in order to make the rewards system more financially sustainable and to help the organizations align the reward system with business goals, achieve an increasing degree of employee attraction, motivation and retention. The increasing diversification of the types of rewards awarded is also intended to ensure the satisfaction in the workplace of as many employees as possible from an increasingly diversified workforce.

The literature highlights two important factors in establishing reward systems. The first factor is based on analysing employee preferences for certain types of rewards in order to implement a reward system that meets the needs of as many employees as possible, but focusing on the preferences of employees with a high level of knowledge and qualification, which are basically the employees who have the greatest contribution in achieving the organization's performance objectives and ensuring a high level of competitiveness. The second aspect to be pursued in the construction of the rewards system is that they must be based on the principle of internal equity (rewards to be awarded non-discriminatorily according to performance, position within the organisation, responsibilities, experience and qualifications), on the principle of external equity (rewards granted to be similar to those granted in the labour market) and can be borne by the company's budget.

Surveys undertaken in recent decades show that, while there have been many organisations that have set out to introduce effective reward management, very few have succeeded in this endeavour. They also showed that few of the organisations that had implemented total management had achieved the expected results from its implementation. We consider these issues to be very interesting themes for future research.

\section{Acknowledgment}

There was no external funding.

\section{References}

- Adeoye, A. O. and Fields, Z. (2014) 'Compensation Management and Employee Job Satisfaction: A Case of Nigeria', Journal of Social Sciences, 41(3), 345-352. 
- Adeoye, A.O., Atiku, S.O. and Fields, Z. (2016) 'Structural Determinants of Job Satisfaction: The Mutual Influences of Compensation Management and Employees' Motivation', Journal of Economics and Behavioral Studies, 8(5), 27-38.

- Aksakal, E. and Dağdeviren, M. (2014) 'Analyzing Reward Management Framework with Multi Criteria Decision Making Methods', Procedia - Social and Behavioral Sciences, $147,147-152$.

- Alhmoud, A., and Rjoub, H. (2020) 'Does Generation Moderate the Effect of Total Rewards on Employee Retention? Evidence From Jordan', SAGE Open July-September 2020, 1-15.

- Armstrong, M., and Brown, D. (2006) Strategic Reward: Making it Happen, Kogan Page Limited, London and Philadelphia.

- Armstrong, M. and Taylor, T. (2014) Armstrong's handbook of human resource management practice, Kogan Page Publishers, New York.

- Brown, D. (2018) 'Fairness, flexibility and affordability. What are the lessons from recent pay and reward approaches and trends in the UK?', Institute for Employment Studies (February 2018), 1-21.

- Bussin, M. and Van Rooy, D.J. (2014) 'Total rewards strategy for a multi-generational workforce in a financial institution', SA Journal of Human Resource Management, 12(1), 1-11.

- Bussin, M. and Toerien, W.C. (2015) 'Influence of reward preferences in attracting, retaining, and motivating knowledge workers in South African information technology companies', Acta Commercii, 15(1), 1-13.

- Bustamam, F.L., Teng, S.S. and Abdullah, F.Z. (2014) 'Reward management and job satisfaction among frontline employees in hotel industry in Malaysia', Procedia-Social and Behavioural Sciences, 144, 392402

- Bwowe, P. W. and Marongwe, N. (2018) 'Implementing a total reward strategy in selected South African municipal organisations', SA Journal of Human Resource Management, 16, 1-9.

- Day, J. W., Holladay, C. L., Johnson, S. K. and Barron, L. G. (2014) 'Organizational rewards: considering employee need in allocation', Personnel Review Journal, 43(1), 74-94.

- Delloite (2018a) 'Rethinking rewards: How personalized programs can attract and retain talent', CFO Insights June 2018, [Online], [Retrieved October 26, 2020], https://www2.deloitte.com/us/en/ pages/finance /articles/cfo-insightsrethinking-rewards-retaining-talent.html - Deloitte (2018b) 'The rise of the social enterprise', 2018 Deloitte Global Human Capital Trends, [Online], [Retrieved October 26, 2020], https://www2.deloitte.com/content/dam/in sights/ us/articles/HCTrends2018 /2018HCtrends_Rise-of-the-social-enterprise.pdf

- Dessler, G. (2016) Human Resource Management, 15th Edition, Pearsons Education, Inc., Boston.

- Fernandes, F. N. (1998) 'Total reward - an actuarial perspective (Actuarial Research Paper No. 116)', Faculty of Actuarial Science \& Insurance, City University London, London, UK.

- Greene, R.J. (2014) 'The Role of Employee Ownership in the Total Rewards Strategy', Compensation and Benefits Review, 46(1), 69.

- Gross, S. E. and Friedman, H. M. (2004) 'Creating an Effective Total Reward Strategy: Holistic approach better supports Business Success', Benefits Quarterly, Third Quarter 2004, 20 (3), 7-11.

- Heneman, R.L. (2001). Business driven compensation policies. Integrating Compensation Systems with Corporate Strategies. New York: AMACOM, a division of American Management Association - Jiang, Z., Xiao, Q., Qi, H. and Xiao, L. (2009) 'Total Reward Strategy: A Human Resources Management Strategy Going with the Trend of the Times', International Journal of Business and Management, 4(11), 177-183. 
- Kaplan, S. L. (2007) 'Business Strategy, People Strategy and Total Rewards', Benefits \& Compensation Digest, 44(9), 12-19, [Online], [Retrieved October 24, 2020], https://studylib.net/doc/8159748/business -strategy-people-strategy-and-total-rewards

- Khan R.I., Aslam, H. D. and Lodh, I. (2011) 'Compensation management: A strategic conduit towards achieving employee retention and job satisfaction in banking sector of Pakistan', International Journal of Human Resource Studies, 1(1), 89-97.

- Martocchio, J. J. (2017) Strategic compensation: A human resource management approach, 9th Edition. Pearsons Education, Inc., Boston.

- Maung, W.W. and Walsh, J. (2016) 'Determinants of Selected Compensation Management on Employees' Satisfaction of Heavy Machinery Companies in Mandalay', Recent Issues in Human Resource Management, 1(1), 1-25.

- McCormick, H. (2015) 'Rethinking total rewards', Kenan-Flagler Business School, UNC Executive Development, [Online], [Retrieved September 10, 2020], https://www.kenanflagler.unc.edu/

- Medcof, J.W. and Rumpel, S. (2007) 'High technology workers and total rewards', The Journal of High Technology Management Research, 18, 59-72.

- Milkovich, G.T., Newman, J.M. and Gerhart, B. (2014) Compensation, 11th Edition, McGraw-Hill, New York.

- Milne, P. (2001) 'Rewards, Recognition and Knowledge Sharing: Seeking a Causal Link', Australian Academic \& Research Libraries, 32(4), 321-33.

- Pregnolato M. (2010) 'Total Rewards that retain: A study of demographic preferences', A dissertation submitted in partial fulfillment of the requirements for the award of the degree of Master of Social Science in Organisational Psychology.

- Robbins, S.P., DeCenzo, D.A., Coulter, M. and Anderson, I. (2013) Fundamentals of
Management, 7th Canadian Edition, Pearson, Toronto.

- Rumpel, S. and Medcof, J. W. (2006) 'Total rewards: good fit for tech workers', Research Technology Management, 49(5), 27-35.

- Tropman, J. E. (2001) The compensation solution: how to develop an employee-driven rewards system, University of Michigan Business School and management series. Wiley eBooks.

- WorldatWork, (2011) Total rewards model. A framework for strategies to attract, motivate and retain employees, WorldatWork Press, Scottsdale, Arizona, [Online], [Retrieved October 12, 2020], http://www.sullivanhi.com/pdf/TotalRewards-Inventory.pdf

- WorldatWork, (2008) Total rewards model. A framework for strategies to attract, motivate and retain employees, WorldatWork Press, Scottsdale, Arizona, [Online], [Retrieved October 12, 2020], https://spanopratt.com/wpcontent/uploads/2011/05/World-at-WorkTotal-Rewards.pdf

- WorldatWork, (2010) The relative influence of total rewards on attraction, motivation and retention, WorldatWork Press, Scottsdale, Arizona, [Online], [Retrieved October 12, 2020], https://www.worldatwork.org/docs/researc $\mathrm{h}$ - and - surveys/worldatwork -sponsoredresearch / research-report-the-relativeinfluence-of-total-rewards-elements-onattraction-motivation-and-retention.pdf - WorldatWork, (2015) Total rewards model. WorldatWork Press, Scottsdale, Arizona, [Online], [Retrieved October 12, 2020], https://www.worldatwork.org/docs/market ing/1610_ BRO_TRModel_Update _J5613_FNL.pdf

- WorldatWork, (2020) Total rewards model, [Online], [Retrieved October 12, 2020], https://www.worldatwork.org/docs/market ing/2020_BRO_TRModel_J16197_FNL.pdf 


\section{Electronic References}

-https://www.iedunote.com/compensationmanagement

-https://www.willistowerswatson.com/enGB/Solutions/services/total-rewardsstrategy

-https://worklifebalance.com/worklifeeffectiveness/

- https://gulfnews.com/uae/relationalcompensation---a-return-which-is-not-seen1.387008

- https://www.pewresearch.org/facttank/2018/04/11/millennials-largestgeneration-us-labor-force/

- https://hrsoft.com/blog/totalcompensation-vs-total-rewards/

- https://www.linkedin.com/pulse/totalcompensation-vs-rewards-difference-ali-elbreashy-assoc-cipd/

-https://www.talentlyft.com/en/resources/ what-is-employee-value-proposition-evp
- https://www.hibob.com/hr-

glossary/compensation-managementplanning/

-https://redditblog.com/2020/10/27/evolvi ng-reddits-

workforce/?fbclid=IwAR3psd0Icyo140NsRO TS9V-6-8Jd10-4QpZzLFyhRieO-

A5t9ePOjx0lvuw

-http://www.cipd.co.uk/subjects/pay/gener al/totrewdqf.htm

- https://management.co.nz/article/whyyou-should-consider-total-rewards-model - https://www.prnewswire.com/newsreleases/deloittes-bersin-finds-rewardsprograms-are-a-key-element-to-talentretention-and-improved-performance300631597.html

•https://deloitte.wsj.com/cfo/2018/06/26/ rethinking-rewards-how-personalizedprograms-can-attract-and-retain-talent/ - https://www.worldatwork.org/totalrewards-model/ 